\title{
US Trade Deficits and Sino-US Relations
}

\author{
LEONG H. LIEW \\ Department of International Business \& Asian Studies, Griffith University, Queensland, Australia
}

ABSTRACT American politicians and policy makers have blamed China's exchange rate for the large US trade deficits. This paper explains why the USA treats its trade deficits with China as a security issue that have become a source of friction in Sino-US relations. The essay argues that this friction is a useful de flection from the politically difficult policy action needed to remedy the US economy and cannot easily be removed by the Chinese side alone. The structure of global trade and the reality of China's political economy, which forces Chinese leaders to develop policies for a "harmonious society" in the face of growing inequality also makes it difficult for China to respond positively to US pressure on the exchange rate.

KEY WoRDS: Trade imbalances, Sino-US relations, exchange rate, globalisation

At the end of 2008 the value of China’s foreign reserves was US\$2 trillion, an increase of US\$1 trillion in just two years (World Bank, 2009a: 12). In 2006, China displaced Japan as the country with the largest trade surplus with the USA. Contemporaneously, China has replaced Japan in the minds of many Americans as the country that posed the greatest challenge to America's economic superiority. In this context, US political players have made the value of the yuan a useful strategic scapegoat for the mounting deficits in US trade, and fuel for the notion that China uses such tactics strategically, to impair the US economy.

Many US Congress members of both major parties blame China for the large US trade deficits through what they cast as China's deliberate undervaluation of the Chinese yuan. In 2007, four senators - Max Baucus, Chuck Grassley, Charles Schumer and Lindsey Graham - introduced into the Congress a bill, co-sponsored by the leading contenders for the Democratic nomination for the 2008 presidential election, Hillary Clinton and Barack Obama, to impose anti-dumping duties against China's imports into the USA and to bring a trade case against China in the WTO (Callan, 2007). Obama had earlier requested in a letter to Treasury Secretary Henry Paulson that the US Treasury reconsider its decision not to classify China as a currency manipulator to protect the interests of American businesses and American workers (Obama, 2007). After the presidential election, Timothy Geithner, Obama’s nominee as Treasury Secretary, labelled China a currency manipulator during his Senate confirmation hearing before he retracted his comments after complaints from China.

This article examines how and why US political players have linked their nation's bilateral trade deficits to China's exchange rate policy and explores the consequences for Chinese policy 
makers. I argue that by casting the value of the yuan as a major reason for US trade imbalances, US players have made China's exchange rate a reason to asperse China's economic performance and an important factor in Sino-US relations. Many US citizens are influenced by media reports that cast China as the "big bad wolf"' of globalisation and the major cause of their country's economic woes, including loss of manufacturing jobs, rising debt and increasing economic insecurity. This specious view has gained firm ground even though China's policy-makers' influence on US trade deficits is limited by the global structure of processing trade and by US public and private savings and consumption behaviours. The view also holds an inherent contradiction about responsibility since the USA refuses to export advanced technology goods to China on grounds of national security and therefore can be seen as not maximising its exports to China. ${ }^{2}$ Yet, for US political players in the business of attributing blame, the yuan exchange rate is a matter over which the Chinese government hasfinal control and thus it can be treated e ffectively as a major cause of increasing serious US economic insecurity. It serves as an extremely useful deflection from the politically difficult policy action needed to remedy the US economy.

In the dominant US perspective, fault sits firmly on the Chinese side. This view claims that the low value of the yuan, coupled with freedom for China to export into the USA, are responsible for the flood of cheap Chinese goods on which many US economic dilemmas can be blamed. By weakening the US economy and strengthening China's, this export flow has helped to position post-Mao China not just as an economic powerhouse but as a serious challenge to US global dominance economically, politically and potentially even militarily.

In the dominant Chinese perspective, however, exchange rate is not a strategic weapon to undermine any other economy. Although a case can be made for a more flexible exchange rate, the freedom of China's policy makers to vary exchange rate policy to influence US trade deficits is constrained not just by the structural and behavioural factors mentioned above but also by the demands of China's domestic political economy. Here we see how the official views on both sides of the Pacfic begin with attention to domestic need - the Chinese for political and economic stability, the USA for a scapegoat for mounting trade deficits, public and private debt and declining employment opportunities in manufacturing.

\section{US Responses to China's Economic Rise}

Debates in US policy-making circles over China's economy and the value of the yuan have precedents in debates during the 1980s over Japan's economy and the value of the yen, when the USA perceived the strengthening of Japan's economy as a threat. Concern in the USA then was the rapid rise of the Japanese economy and perceived invincibility of the "Japanese model" of a state-led economy, paralleling the perceived decline in US economic prowess. A concept then 
popular in East Asia explained Japan's position as Asia’s leading goose in the so-called “flying-geese”, model of catch-up growth, while then Malaysian prime minister, Mahathir Mohamed, openly advocated a "Look East policy” for Malaysia. But the bursting of what was subsequently recognised as Japan's bubble economy in the late 1980s ended the adulation and adoption of the Japanese model. With the post-bubble Japanese economy unable to reproduce its pre-bubble impressive growth rates, in the new millennium the concern of US policy makers has shifted to the latest booming economy, away from Japan and the yen to China and the yuan. The break-up of the Soviet Union soon after Japan's “economic miracle” ended left the USA as the world's sole superpower. Now, in the middle of the global financial crisis, it is the Chinese economy that remains the only credible driver of economic growth across Asia-Pacific and the major source of funding for US current account deficits.

The shift in attention of US policy makers from Japan and the yen to China and the yuan has been brought about by China's economic rise from late in the twentieth century. China's “'rebirth,” as Henry Kissinger calls it, "raises massive global economic challenges that cannot be ignored" and marks "a shift in the center of gravity of world affairs from the Atlantic to the Pacific" (Kissinger, 2004: 30). It results from the nation's post-Mao economic reform towards marketisation and re-engagement with the global economy, which propelled China's GDP in purchasing power terms to the world's second largest, only after that of the USA. By 2004 China's GDP was $13.2 \%$ of world GDP, compared to $20.9 \%$ for the USA. China's share of world GDP was then almost double Japan's share (6.9\%) and only marginally smaller than that of the Euro area (15.3\%), but it was more than double that of the other rising Asian power, India (5.9\%) (IMF, 2005: 193).

China's foreign trade, as a conduit of modern technology and management know-how into China, has made a major contribution to China's post-Mao rapid economic growth. It has also contributed significantly to the growth in world trade and Asia's economic growth. From 1979 to 2003 China's foreign trade grew at an average annual rate of $15 \%$, compared with an average annual expansion in world trade of 7\% over this period (Prasad and Rumbaugh, 2004: 1). In 2008, China (8.9\%) ranked second in the world after Germany $(9.1 \%)$ in the share of merchandise exports. With a share of 6.9\%, it ranked third after the USA (13.2\%) and Germany (7.3\%) in world merchandise imports (WTO, 2009: 18).

Export growth has enabled China to accumulate large current account surpluses and foreign reserves. China's current account surplus reached a peak of 11.3\% of GDP in 2007 (World Bank, 2009a: 12), most of it through trade with the USA, although it fell to $9.6 \%$ in 2008 , as a result of the global financial crisis. The 2008 US trade deficit with China was about two-and-a-half times the equivalent deficit with Japan, which ranked second, and represented $33.3 \%$ of the total US 
trade deficit of US $\$ 800$ billion (Table 1). The USA, responding to its increasing trade deficits with China, established the US-China Economic and Security Review Commission (USCC) "to monitor, investigate, and report to Congress on the national security implications of the bilateral trade and economic relationship between the United States and the People's Republic of China [PRC]'" (USCC, 2004: iii). That Congress has established this Commission to report to it on the strategic implications of Sino-US economic relations is indicative of the US suspicions about China's international trade and investment policies. The US government regards what it casts as China's unfair trade practices, including manipulation of the value of the yuan, as a major contributor to growing US trade deficits (USCC, 2007: 7).

Table 1. US balance of trade deficit by major countries (2008)

\begin{tabular}{lcc}
\hline & US\$ billion & Share (\%) \\
\hline Total (census basis) & 799.9 & 100.0 \\
China & 266.3 & 33.3 \\
Japan & 72.7 & 9.1 \\
Canada & 74.6 & 9.3 \\
Germany & 42.8 & 5.4 \\
Mexico & 64.4 & 8.1 \\
OPEC & 175.6 & 22.0 \\
OPEC, Canada \& Mexico & 314.6 & 39.3 \\
Rest of the world & 103.5 & 12.9 \\
\hline
\end{tabular}

Source: UCB (2008).

\section{US Deficits and US Security}

For a number of reasons, US authorities view the large deficit in the US balance of trade with China as a security issue. First, there is a perception, held widely at official and popular levels in the USA, that continuous trade dficits reflect ongoing US de -industrialization. A USCC report stated that China's trade policies “are serving to hollow out the US manufacturing base” (USCC, 2006: 168) and "China has become [for many in the US] the poster child for those aspects of globalization that threaten the United States”' (Lampton, 2005: 67). It is not surprising that US manufacturing unions are the members of organised labour most in favour of US sanctions against Chinese imports.

The second reason concerns the relationship between US trade deficits and rising US international debt. Until 1989, the USA was a net creditor to the rest of the world. However the US international investment position (NIIP) ${ }^{4}$ has deteriorated, gradually in the early 1990s but rapidly in the late 1990s, as its trade deficits worsened and, in the 2000s, the USA became the world's 
biggest debtor nation. According to the Bureau of Economic Analysis the USA at the end of 2007 owed the rest of the world a net US\$2.4 trillion, as measured by its negative NIIP. Compared to a net US\$1.1 trillion it owed at the end of 1997, this represented a 100\% plus increase (BEA, 2008; Scholl, 1999). Continuing large US trade deficits are rapidly increasing the external debt and reinforcing its position as the world's number-one debtor, while deepening its dependence on foreign purchases of dollar assets.

More worryingly for US policy makers, central banks in Asia, especially those of China and Japan, were the largest purchasers of dollar securities. At the end of 2008, China and Japan between them held $44 \%$ of US Treasury securities (Table 2). Neoconservative Aaron Friedberg (2000), in a controversial and widely discussed article that fuelled the China threat scenario, suggested that China could use the dollar-denominated assets at its disposal as an economic weapon against the USA; China could dump the assets to raise US interest rates or trigger a run on the dollar or even a stock-market crash. Friedberg suggested that because such a tactic could also damage the Chinese economy, it would have the same effect as using nuclear weapons: mutual devastation. But even mutual devastation, he argues, is no guarantee that China will not use this potential "'weapon."

Table 2. Foreign holdings of US Treasury securities (US\$ billion)

\begin{tabular}{lcc}
\hline & End of December 2008 & Share (\%) \\
\hline China, Mainland & 727.4 & 23.6 \\
Japan & 626.0 & 20.3 \\
Carib Bnkng Ctrs & 197.5 & 6.4 \\
Oil exporters & 186.2 & 6.1 \\
UK & 130.9 & 4.3 \\
Brazil & 127.0 & 4.1 \\
Russia & 116.4 & 3.8 \\
Luxembourg & 97.4 & 3.2 \\
Hong Kong & 77.2 & 2.5 \\
Taiwan & 71.8 & 2.3 \\
Switzerland & 62.3 & 2.0 \\
Germany & 56.1 & 1.8 \\
All other & 600.7 & 19.5 \\
Grand total & 3076.9 & 100.0 \\
\hline
\end{tabular}

Source: USDT (2009) and author's calculations.

The third reason for the USA viewing its trade deficit with China as a security issue concerns the capacity that thisfinancial strength provides China for leverage in the global economy. The Economist (2004: 65), in a special issue on the future of the US dollar, points out that in 1913 Britain was at the height of its empire building and the world's largest creditor, but it became a net 
debtor 40 years later, allowing the dollar to usurp the role of the pound sterling as the world's reserve currency. The transformation in Britain's position from the world's biggest creditor to a net debtor nation is rich in historical lessons. Various interpretations explain the precise relationship between the downward shift in Britain's international investment position and Britain's loss of empire status, but being the world's biggest debtor over time can only increase the economic vulnerability of the USA and undermine its status as the world's sole superpower.

Nye (2005) argues that China is a long way behind America in exercising “'soft power," 5 but he acknowledges that China is catching up. In Southeast Asia, Kurlantzick (2006) argues that China's soft power may have already surpassed that of America. No doubt China's growing soft power relative to that of the USA is fuelled by factors beyond its dynamic economy and bloating foreign reserves; the Bush administration's post-9/11 missteps come easily to mind. But the contribution of China's international economic engagements is surely a vital component. Economic engagements through trade, commerce and so forth provide the channel through which culture, ideas and values flow out from China and in the process also serve to demonstrate China's soft power. The income they generate also increases China's economic power and its financial capacity to further develop military and political power such that China can pose a serious challenge to America's irfluence in the world. As evidence of China's growing influence, many policy makers and the media have taken on board Zbigniew Brzezinski's suggestion that China and the USA form a group of 2 - a G2 - to tackle the globalfinancial crisis (see Economy and Segal, 2009). And Browne (2006) claims that the prospect of China increasing its influence in emerging markets by lending to developing countries unhappy with conditions of IMF loans worries US officials even more than the potential dumping of dollar assets by China as Friedberg speculated.

A final reason for the USA viewing its trade deficit with China as a security issue stems from the point discussed above. Greater economic strength and greater foreign exchange reserves increase China's competitive capacity vis-a`-vis the USA - to acquire energy, to finance significant improvements in science and technology, and to acquire foreign defence and defence-related technology. Heavy dependence on imported oil has put the USA into increasing competition with China and other emerging economies (Victor et al., 2008). Thompson (2007) explains how China is drawing from its vast foreign exchange supply to compete with the USA for oil in Africa, which has become an important source of US energy. The Gulf of Guinea supplied more oil to the USA in 2005 than Saudi Arabia and Kuwait combined. Thompson (2007: 3) claims that by 2017, Africa will supply more oil to the USA than the entire Middle East. As then Deputy Secretary of State, Robert B. Zoellick, in a speech to the National Committee on US-China Relations, drew a link between the US administration's constant criticism of what it perceives to 
be China's unfair trade practices and the 2005 bid by China National Offshore Oil Corporation (CNOOC) for Union Oil Company of California (UNOCAL), opining that China's mercantilist efforts to “'lock up”' energy supplies are “not a sensible path to achieving energy security” (cited in Kessler, 2005: A16).

In 2006, China spent more on research and development (R\&D) than Japan and became the world's largest investor in R\&D after the USA (OECD, 2006). The 2005 Report of the Task Force on the Future of American Innovation, whose members included representatives from Lucent and Microsoft, concluded with a note of caution that "China has been investing heavily in nanotechnology and already leads the US in some areas . . . and is making rapid progress in biotechnology' (cited in Preeg, 2005: 8). In its 2004 report to the US Congress, the Department of Defense noted how rapid economic growth has enabled China to devote more resources to enhancing its military capability with significant purchases of defence and defence-related technology from France, Germany, Israel, Italy and Russia (USDOD, 2004). A government-sponsored Rand study with a similar orientation points out that the Chinese People's Liberation Army strategy is geared increasingly to fighting wars "under high-technology conditions"' (Cliff et al., 2007).

Military-industrial complexes everywhere have an incentive to exaggerate military threats to national security, and the " China threat'” has become a convenient vehicle for entrenched interests in the US military and industry to gain more public resources. These entrenched interests, according to an editorial in the Christian Science Monitor (2009), receive support from a military-industrial-congressional network that had overseen a near twofold increase in donations to federal political campaigns from defence-related donors since 2000.

Americans have come to view China as more of a threat than they ever viewed Japan, even at the height of “Japan fever”' in the 1980s. Many observers in the USA point to market fervour in China and reject the Communist Party's claim that the PRC is “'communist”' in any shape or form, but China is nevertheless regarded as America's remaining major ideological competitor. Samuel Huntington's provocative 2005 book, Who Are We? America's Great Debate, suggests reasons. Here Huntington (2005: 261) argued that the USA needs to have "'a clear 'other' against which to define itself." He claimed the USA is a glaring exception among developed countries in terms of its high level of religiosity - 65\% of its population affirmed strong religiosity - making moralism as much the guide to US foreign policy as realism (Huntington, 2005: 80, 88, 91). He argued that the USA lost a clear " other" after the collapse of communism in Eastern Europe and of the Soviet Union. China is an ideal candidate tofill this void since it looms large not merely as a strategic competitor but in recent history has avowed atheism; only about 5\% of its population affirmed strong religiosity (Huntington, 2005: 91, 267). Huntington’s identifying of the need for an enemy 
“other" appears to have some basis, although grounding his analysis in the "religiosity" of nations may have more to do with morally justifying US foreign policy - to Americans at least than illuminating the real source of Sino-US tensions.

\section{Global Processing Trade and China's Trade Surplus}

About half of China's exports are based on "triangular trade," where the final processing and assembling of exports from China's OECD neighbours - Japan and South Korea - is performed in China for dispatch to markets in Europe and North America. The result of this triangular trade is that China's increasing trade surpluses with North America are accompanied by increasing trade deficits with many countries in Asia (Greene et al., 2006: 5). This empirical finding is corroborated by the research of Lau and colleagues (2006), who estimated that in 2002 the domestic value-added of China's exports to the USA was only 36.8\%, which is far lower than the $87.3 \%$ domestic value-added of US exports to China. Linden and colleagues (2009: 144) provide further supporting evidence at the product level. They found that every iPod imported from China and sold in the USA for US\$299 increased US trade deficit with China by US\$150, but the assembly work in China only value-add "a few dollars." Assembling the iPod in the USA would require importing components from countries that had originally exported these components to China for assembling and not reduce the overall US trade deficit. "Triangular trade" is a veil that exaggerates the significance of US trade deicits with China. Bilateral trade deicits are gross deficits. They are not net deficits that measure the gap in the export and import of value-added, which are a better indicator of the state of the Sino-US trade relationship.

Thus, many analysts, including Jonathan Anderson (2004, 2007), chief Asian economist at the investment bank UBS, and Stanley Roach (2004), Morgan Stanley's chief economist, do not believe revaluing will make much difference to US trade deficits. A higher value yuan makes China's exports more expensive on international markets, but it also lowers the input costs of these exports. Moreover, China has extremely low domestic manufacturing labour costs, about 3\% of those in the USA, a quarter of those in Brazil and Mexico and less than 10\% of the average cost of Hong Kong, South Korea, Singapore and Taiwan (Banister, 2005: 32). Even though China's labour costs have been rising and labour productivity in China remains low, it is unlikely that any conceivable revaluation of the yuan could make US manufacturers competitive in producing the labour-intensive and basic technology manufacturing goods that the USA is importing in large quantities from China. An important reason is that manufacturing wages' growth in China responds to changes in the exchange rate.

Mckinnon (2005a, 2005b) pointed out that growth in money wages in the ten years since the mid-1990s in China had tracked growth in labour productivity in China's most open tradable 
sector - manufacturing - and made the rate of irflation in China converge with that of the USA, keeping international competitiveness in balance. But if the exchange rate were not anchored and appreciation seemed likely, employers in China would have been more cautious when bidding for labour and wage growth would have fallen below the rate of productivity growth. Manufacturing wages in China are veryflexible, because unions are weak and labour highly mobile and China's policy makers can expect that a policy to raise the value of the yuan would be compensated in China with lower wage growth, which would leave US trade deficits with China largely unaffected. Policy makers may vary the nominal exchange rate, but they cannot control the real exchange rate. ${ }^{6}$

Sino-US trade tensions are likely to increase further as China moves up the value-added chain from a very low base. The Fifth Plenum of the 14th Party Congress in 1995 signalled that China was to embark on an industrial policy of " picking winners"' to develop world class businesses (Liew, 2000: 153-4). China's political leaders are aiming for China to reach industrial power status, an aim now popularly supported in China. Chinese industry with government support is able to export goods normally associated with a country that has a productivity level much higher than China's (Rodrick, 2006), and this is posing a threat to parts of the US automobile industry (Bradsher, 2007; USCC, 2006: Ch. 4). But, as the research of Linden and colleagues (2009) on the iPod pointed out, being able to export high value goods does not necessarily indicate a country's capacity to add value in production. Most of the value in high value goods exported from China is created elsewhere and imported by the country as input into export production.

Nolan's (2002) extensive investigation into China's major corporations reported that they have not achieved world class status. A later study (Kiely, 2008: 367) also concludes that the success of China's “national champions", has so far been limited. Nevertheless, although China's industrial policy is not an unqualified success, China is still able to climb up the technological ladder and increase its share of value-added in exports. ${ }^{7}$ Currently, high domestic value-added exports remain a relatively small proportion of China's exports as research demonstrates, but China is fast catching up. In 1995, the domestic value-added of China's exports to the USA was only 20\% (Lau, 2003). ${ }^{8}$ Furthermore, in a sector like automobiles this can become a sensitive issue for Sino-US relations because of the significant historical role that the automobile played in US industrialisation and the big automobile remains for many Americans an icon of their country's way of life and technological prowess.

However, China's climb up the value-added chain need not increase Sino-US trade tensions if the US trade strategy responds strategically by restructuring the national economy away from low value-added, low-skill intensive industries and exports to China its advanced technology products that China is partly able to access from other sources anyway. But this goes against US preference 
for investing in prisons over education (JPI, 2007: 14) and fear that Chinese may use US exports of advanced technology goods to further develop China's own military capabilities (AFP, 2007; Jiang, 2007; on export policy, see BIS, 2007). China still lacks the capacity to produce many advanced technology goods and, in the short term, needs to import these goods until Chinese technology development is brought to an advanced level through domestic R\&D and adaptation of technologies in imported goods, as other nations such as Japan have done. Regardless of the reasons behind US restrictions on sales of advanced technology goods to China, these restrictions make it harder for China and the USA to address their massive bilateral trade imbalance.

\section{Foreign Trade and China's GDP}

Since much of China's foreign trade is triangular, as discussed above, the contribution of China's foreign trade in expenditure terms to its GDP growth since 1998 has been, contrary to popular perception, relatively modest compared to contributions from domestic consumption and investment. China's GDP growth is largely driven by domestic, not foreign, demand (Table 3). The importance of foreign trade for China's GDP growth lies more in the technology and management know-how that foreignfirms exporting from China introduced into the country. In the wake of the 1997 Asian economic and financial crisis, in 1999 net demand of the foreign sector actually reduced China's GDP growth. But because the volume of China's exports and imports is so large and growing rapidly at different rates, even though the difference in export and import growth rates is small, the absolute size of the gap between exports and imports is large, exaggerating the actual contribution of foreign demand to growth in China's GDP and employment. Moreover, net foreign trade began to make a significant contribution to China's economic growth only in 2005. Much of net foreign trade's 25\% contribution to China's total economic growth in 2005 was due to exports to the USA, which generated 36 million person-years of employment in China (Lau et al., 2006). This appears to be a considerable amount, but a simple calculation shows that it represents only $4.75 \%$ of the total 758.25 million officially recorded in employment for that year (NBS, 2006: 125). 
Table 3. Share and contribution of various final demands to GDP growth (\%)

\begin{tabular}{ccccc}
\hline & Consumption & Gross capital formation & Net exports goods \& services & GDP \\
\hline 2001 & 50.0 & 50.1 & -0.1 & 8.3 \\
& 4.1 & 4.2 & 0 & \\
2002 & 43.6 & 48.8 & 7.6 & 9.1 \\
& 4.0 & 4.4 & 0.7 & 10.0 \\
2003 & 35.3 & 63.7 & 1.0 & \\
& 3.5 & 6.4 & 0.1 & 10.1 \\
2004 & 28.7 & 55.3 & 6.0 & 10.4 \\
& 3.9 & 5.6 & 0.6 & 11.6 \\
2005 & 38.2 & 37.7 & 24.1 & \\
& 4.0 & 3.9 & 2.5 & 13.0 \\
2006 & 38.7 & 42.0 & 19.3 & \\
& 4.5 & 4.9 & 2.2 & 9.0 \\
\hline \multirow{2}{*}{2008} & 40.6 & 39.7 & 19.7 & 2.6 \\
& 5.3 & 5.1 & 9.5 & \\
& 45.7 & 45.1 & 0.8 & \\
\hline
\end{tabular}

Source: NBS (2009: table 2.20) and author's calculations.

\section{US Savings and Trade Deficits}

US savings and spending behaviours are central to understanding the mounting trade deficit. It is, after all, the excess of purchase of imported goods and services by Americans - government and citizens - over sales by USA to China and elsewhere that has created the trade de ficit. Here we see that the large US consumption and investment that helps produce the trade deficit is funded inside the USA not by taxes or private savings but by dis-saving by both government and households.9 Ben Bernanke (2005), the chair of the Federal Reserve, attributed part of the blame of the large US trade deficits to the large savings of the Asian economies, especially China. But even if China had saved much less, it would have imported more from other countries rather than the USA, because of US controls on exports to China. Moreover, Bernanke neglected to mention two related US government key policy decisions of the previous Republican administration that were responsible for the massive drop in national savings in the USA.

Unlike previous administrations that raised taxes to finance foreign wars, the George W. Bush administration made large tax cuts while conducting its enormously expensive war in Iraq. It raised real federal spending by $4.9 \%$ per year - most of it labelled as defence, which registered a real annualised growth rate of $8.1 \%$, compared to $4.9 \%$ under Lyndon Johnson whose administration (1963-69) financed the Vietnam War (Rogers, 2006; Tebbs, 2007). This Bush administration shifted the US government budget from a 1.8\% of GDP surplus at the end of the 
Clinton administration in 2001 to a $4.8 \%$ deficit at the end of hisfirst term (Table 4), with the federal debt ballooning to about US\$4.2 trillion at the end of his second term (USG, 2009: 128). Not only is the American government dis-saving, Americans citizens are dis-saving too. In the second quarter of 2005, the personal saving rate in the USA became negative for the first time since the Great Depression (Rogers, 2006). Deficit in the US government budget, together with progressively lower, then negative, US household savings contributed to an excess of expenditure over production in the USA. Imports have to fill the gap when expenditure exceeds production and, since much of the imports are from China, this has exacerbated the trade deficit with China.

Table 4. US total government fiscal budget (2000-07)

\begin{tabular}{lccccc}
\hline & \multicolumn{2}{c}{ Budget surplus/deficit } & & \multicolumn{2}{c}{ \% of GDP } \\
\cline { 2 - 3 } \cline { 5 - 6 } Fiscal year & Total & Federal & & Total & Federal \\
\hline 2000 & 172.2 & 236.2 & & 1.8 & 2.4 \\
2001 & 25.3 & 128.2 & & 0.3 & 1.3 \\
2002 & -322.7 & -157.8 & & -3.1 & -1.5 \\
2003 & -554.9 & -377.6 & & -5.1 & -3.5 \\
2004 & -554.9 & -412.7 & & -4.8 & -3.6 \\
2005 & -435.0 & -318.3 & & -3.6 & -2.6 \\
2006 & -384.1 & -248.2 & & -3.0 & -1.9 \\
2007 & -322.5 & -162.0 & & -2.4 & -1.2 \\
\hline Source: USG
\end{tabular}

Source: USG (2009: 326-7).

A change in the nominal dollar-yuan exchange rate may not affect the real exchange rate as mentioned earlier, but even if the real exchange rate were to change it would produce a largely substitution eff ect. What is really required to reduce the level of US spending on total imports rather than simply precipitate a purchasing shift from Chinese to other imports is increased US savings, both private and public. Despite US complaints about the value of the yuan, between 2005 and 2008 the yuan had appreciated about 21.4\% against the dollar. The extent of currency appreciation was greater than the $10 \%$ yuan undervaluation in 2006, estimated by researchers at the highly respected US National Bureau of Economic Research (Cheung et al., 2009), yet the US bilateral deficit with China increased by over $30 \%$ in that period (UCB, 2008). Moreover, yuan revaluation would have little impact on US trade deficits with the major oil-exporting countries, since oil imports are priced in dollars; and the US trade deficits with these countries as a group (OPEC, Canada and Mexico) are larger than its deficits with China (Table 1). 


\section{China's Domestic Political Economy}

China’s policy makers working on exchange rate policy have multiple concerns, the most critical of which is social stability. The 16th CCP Congress in November 2002 and the 9th National People's Congress in early 2003 saw the retirement of both Jiang Zemin as general-secretary of the party and country president, and Zhu Rongji as premier, and their replacement by Hu Jintao and Wen Jiabao, respectively, as general-secretary and president, and Premier. These new leaders are aware that poverty pervades China's countryside and this poses long-term danger for the Party. There is a fundamental shift in emphasis between the Jiang-Zhu and the Hu-Wen leaderships. While the former leadership was deeply concerned with China engaging the global economy and developing world class businesses, the new leadership is more concerned with addressing poverty and income inequality, especially in the countryside and western China, to promote what the government calls a "'harmonious society”' (Xinhuashe, 2006). The proclamation of the new leadership is not mere rhetoric. The new leaders created among policy makers a greater sense of urgency to reduce poverty and inequality. According to the World Bank, Chinese policy makers have implemented a series of programmes in education, health and social security that have achieved impressive results in poverty reduction (World Bank, 2009b).

Jiang and Zhu were just as concerned as their predecessors with social stability. But there are clear reasons why the former leaders were focused more on integrating China into the global economy and obtaining China's WTO membership than on the destabilising effects of globalisation. Jiang became Party leader in 1989 after the most serious public challenge to CCP rule since establishment of the PRC, when in June 1989 troops and tanks were brought in to quell massive demonstrations in Beijing protesting iffation and o fficial corruption at about the time when communism collapsed in Eastern Europe. These two events created a consensus among senior leaders that the CCP could retain power and avoid the fate of the Communist Parties of Eastern Europe only through market reform and engagement with the global economy. Post-Jiang, China is a recognised global economic power and member of the WTO. In this new era, Hu and Wen can afford to be less concerned with rapid enlargement of the size of the national economic pie than with a more equitable distribution of this pie. Chinese reluctance to see their currency appreciate under $\mathrm{Hu}$ and Wen is consistent with their concern for more equal distribution of the economic pie.

The World Bank estimated that China's Gini coefficient increased from 0.29 in the 1980s to 0.39 in the 1990s, transforming China from one of the world's most equal countries (in terms of income) before reform to one in the middle of world rankings by the 1990s (World Bank, 1997: 2). In 2001 income inequality in China worsened further, with the Gini coefficient increasing to 0.45 (UNDP, 2005: 271). According to a World Bank study, the contribution of primary sector (mainly 
agriculture) growth to national poverty reduction between 1980 and 2001 was four times the contribution of secondary and tertiary sectors, despite the fall in the primary sector's share in GDP (cited in Ravallion 2004). Ravallion (2004: 11) poignantly observed that, “'Arguably the bulk of China's trade reform has been after the times of most rapid poverty reduction, and (indeed) in times of relatively stagnant poverty measures.' What these studies clearly demonstrate is that to successfully eliminate poverty in China, the focus of policy has to be on agriculture; globalising the economy does not guarantee continuous poverty reduction. This is not surprising when one realises that the primary sector in 2007 still provided $40.8 \%$ of national employment despite accounting for only 11.3\% of GDP (NBS, 2009:tables 2.2 and 4.3). An appreciating yuan makes imported agricultural goods cheaper and lowers domestic agricultural prices, which disadvantages agriculture even further. As a step in the new direction China's leaders had begun in 2004 to subsidise rather than tax agriculture (Gale et al. 2005).

China's new leadership emphasis on creating a so-called harmonious society will not bring back the equality of the Maoist era. It is clear that China has integrated itself with the capitalist West.10 However, there is a wide spectrum of income inequality among countries that have integrated themselves into the global economy and the Hu-Wen leadership is clearly attempting to reverse some of the significant increases in income inequality resulting from China's post-Mao economic reform.

International discussions over the value of the yuan and US views on this issue have caught the attention of the Chinese public and have led to the numerous publications on this subject. Wang and Zeng (2004: 7) argued that China cannot maintain its position as “factory of the world"' (shijie gongchang) if it relaxes control over the exchange rate. According to Wang and Zeng, revaluing the yuan will weaken China's international competitive position and lower its ability to create much-needed employment. They attribute Japan's recession in the 1990s to the Japanese government's agreement to sign on to the Plaza Accord in 1985 under US pressure, forcing Japan to revalue the yen (Wang and Zeng, 2004: 98). A year earlier, these authors published a popular book with strong nationalist overtones, Jingti Meiguo de dierci yinmou [Be Vigilant against America's Second Plot], criticising US policies toward China. Before the Chinese authorities discontinued the currency peg, there was no shortage of writings in China supporting the peg and criticising international pressure on China to end the peg. Wang's and Zeng's book is just one of many. ${ }^{11}$ 


\section{Conclusion}

The discussion above makes clear that responses on both sides of the Pacific to US trade deficits with China are driven by complex motives that concern domestic economic and political demands. Many US observers, including politicians and other officials, treat the value of China's exchange rate as a thorn in Sino-US relations. However, this “thorn' cannot be removed easily by the Chinese side alone. Yuan revaluation may reduce US trade deficits with China but even this is by no means certain. Certainly it will not signi ficantly reduce bilateral or overall US deficits unless the US increases domestic savings. Without concomitant increases in US savings from reduced spending, yuan revaluation will simply shift US import demand away from China to other countries. And, while possibly reducing the trade deficit with China, it will surely reduce the welfare of US consumers, who will have to pay higher prices. Increasing the value of the yuan impacts negatively on the rural economy and China's leaders will seriously resist this outcome while they try desperately to improve the rural economy, to reduce poverty and income inequality to counter growing unrest in the countryside.

The last two years of the Bush administration saw it mellowing its position on China's exchange rate. It stressed that a more flexible yuan - code for yuan appreciation - is in China's as well as America's interests. It no longer laid the blame of US deficits solely on the yuan. Then US Under Secretary of the Treasury for International Affairs, David McCormick, remarked at Peking University in September 2007 that what a moreflexible yuan "will not do is cause a significant reduction in the US trade deicit, nor will it provide a magic bullet for solving the prob lems of American industries facing overseas competition." He added that the "[US] trade deficit can only be reduced through decisive measures to increase both private and public saving.'” But what it will do, McCormick seemed to say, is to change perceptions about China in the USA for the better by removing "a major cause of the perceived unfairness in [their] bilateral relationship", (McCormick, 2007, emphasis added).

However, a higher yuan will not easily change Americans' perception of China. Accusations by the USA that China's currency is undervalued have been made in a climate where many Americans feel increasingly insecure in their economic relations with China and perceive China as a threat on all fronts to US economic strength and global hegemony. Many US politicians and sections of the media have made China a scapegoat for the challenges that globalisation poses to US producers and workers. They have problematised the value of the yuan to shift blame - and the need for remedial national policy - from some intrinsic but intransigent problems currently burdening the USA as it loses competitive capacity in traditional industries to China and other emerging economies that are quickly mastering the art of competing in global markets. And they will shift their complaint on to some other economic indicator if, as many analysts have predicted, 
a more rapid appreciation of the yuan resulting from a change in China's policy fails to make a significant dent on US deficits.

Some bankers and government officials in the USA have focused on China's purchase of dollar securities to manage its exchange rate. They claim China encouraged risky investments in the USA by keeping interest rates low through its purchases of dollar securities with foreign exchange largely earned from its exports to the USA. Niall Ferguson (2008) encapsulates their views in attributing responsibility for the globalfinancial crisis to "Chimerica" - the symbiotic Sino-US economic relationship - a high-spending US complemented by a high-saving China. But, according to Simon Johnson, a former chief economist of the IMF, the bankers and government oficials are only trying to shift the blame "in a 'buck stops somewhere else' sort of way” away from the "elite business interests" " who played the central role in creating the crisis" to China (Johnson, 2009).

China has no influence on corporate governance in the USfinancial sector. It has also only limited capacity to influence the global changes in the division of labour that continue to push manufacturing production from the rest of East Asia to China and have made China a major centre of manufacturing production for triangular trade. Moreover, China's triangular trade camouflages its low value-added in high value products that it exports and exaggerates its industrial prowess. And more than 25 years after introducing its well-known one-child family policy, China eff ectively can do nothing more about the size of its vast population, which fitates the nation's absolute economic indicators. The indications that result would appear to be much more modest if they were represented in per capita terms. Meantime the enormous size of China's economy, like its population, guarantees that whatever happens to this economy will have a huge impact on the global economy, including its current leader, the USA.

While China's policy makers do not have to contend with professional politicians to the same degree as their counterparts in the USA, they still have to take into account domestic public opinion that considers US pressure on China's exchange rate policy to be an attempt to impede China's economic development. They are also conscious of the view gaining ground in the USA that China's exchange rate policy, like all of China's trade actions, is part of a deliberate, subversive plan to overtake the USA by any means. The complexity and unprecedented nature of this policy dilemma leave China's policy makers still very unsure about the appropriate exchange rate for the yuan, particularly while China's economy is still undergoing massive structural change. The major challenge for China's policy makers is how to keep their commitment to reduce poverty and income inequality, while externally achieve results that will lower tensions with the USA. This conundrum will continue to challenge Chinese national policy makers, especially while US trade deficits are used [in the blame game] to impose US preferences on China's exchange rate 
policy. 


\section{Acknowledgement}

Helpful comments from Dick Bryan and two referees are gratefully acknowledged.

\section{Notes}

Trade deficit is excess of imports over exports of goods and services. Current account deficit is trade deficit plus excess of international transfer payments (such as dividends and interest) over international transfer receipts. Trade flows dominate incomeflo ws in Sino-US trade and magnitudes of trade and current deficits are roughly the same.

${ }^{2}$ Mitchel B. Wallerstein, who was from 1993 to 1997 US Deputy Assistant Secretary of Defense for Counter-proliferation Policy and Senior Defense Representative for Trade Security Policy, argued that US bans on exports of military technology are self-defeating; they weaken not strengthen national security and hurt only US firms (Wallerstein, 2009).

3

It is interesting to note that in July 2007 China, with a population of 1.2 billion, and Australia, with a population of 21 million, had foreign exchange reserves per capita of about US\$1000 and US\$3300, respectively. Australia’s foreign exchange reserves data are available from RBA (2007).

4 NIIP $1 / 4$ (Total stock of US claims on the rest of the world) - (total stock of foreign claims on the USA).

"Nye uses "soft power" to refer to the ability to indirectly influence the behaviour or interests of others through cultural or ideological means. Soft power has since entered popular political discourse as a means to distinguish the subtle effects of culture, ideas and values on others' behaviour from more coercive measures such as military action (hard power) or economic incentives.

6

The nominal exchange rate indicates how much of one country's currency can be exchanged for another. The real exchange rate combines the nominal exchange rate with some measurement of domestic cost. It is, therefore, a better indicator of relative competitiveness between two countries than the nominal exchange of their currencies.

${ }^{7}$ The improved average know-how embedded in the value-added in production in China is not at the lowest, but is still at among the lower and not the upper rungs of the technological ladder. ${ }^{8}$ Lau found in the same study that the domestic value-added of China's exports to the world in 1995 was $30 \%$.

${ }^{9}$ Trade deficit $\mathrm{p}$ net international transfers: net private sector dis-savings $\mathrm{p}$ government budget deficit. This is derived from the national income identity: excess of national spending over income : trade deficit.

10

Thanks to one of the anonymous readers for emphasising this point.

11

In another well-known book, researchers at the Faculty of Finance and at the Contemporary Finance Research Centre, Shanghai Finance and Economics University, interpreted the US pressure on China to revalue the yuan as part of US strategy to slow China's rise (SCD, 2004: 12-13). 


\section{References}

AFP (2007) “'US Tightens High-tech Export Controls for China,’’ http://www.afp.com/english/news/ stories/070616061930.q6iuo858.html, 16 June (downloaded 25 June 2007).

Anderson, J. (2004) '“How I learned to Stop Worrying and Forget the Yuan,’’ Far Eastern Economic Review, 168, 1, pp. 37-42.

Anderson, J. (2007) “'China Should Speed up the Yuan’s Rise,’ Far Eastern Economic Review, 170, 6, pp. 14-20.

Banister, J. (2005) “'Manufacturing Earnings and Compensation in China,’’ Monthly Labor Review, 8, pp. 22-40.

Bernanke, B. (2005) “'The Global Saving Glut and the US Current Account De ficit,' Sandridge Lecture, Virginia Association of Economics, Richmond, Virginia, http://www.federalreserve.gov/boarddocs/ speeches/2005/200503102/de, 10 March (downloaded 21 March 2006).

Bradsher, K. (2007) '“Chinese Auto Parts Enter the Global Market,”' The New York Times, http:// www.nytimes.com/2007/06/07/business/07parts.html, 7 June (downloaded 8 June 2007).

Browne, A. (2006) “'China’s Reserves Near Milestone, Underscoring its Financial Clout,” Wall Street Journal: Asia, 17 October, p. A1.

Bureau of Economic Analysis (BEA) (2008) US Net International Investment Position, http:// www.bea.gov/newsreleases/international/intinv/2008/pdf/intinv07.pdf (downloaded 20 April 2009).

Bureau of Industry and Security (BIS) (2007) US-China Export Control Policy, US Department of Commerce, http://www.bis.doc.gov/ (downloaded 25 June 2007).

Callan, E. (2007) “Clinton and Obama back China Crackdown,’ Financial Times, http://www.ft.com/cms/ s/e628b512-2b20-11dc-85f9-000b5df10621.html, 5 July (downloaded 6 July 2007).

Cheung, Y., M. Chinn and E. Fuji (2009) “'China’s Current Account and Exchange Rate,’ NBER Working Paper, No. 14673.

Christian Science Monitor (2009) '“Why Obama and Gates need Ike to Trim the Military,” http:// www.csmonitor.com/2009/0409/p08s01-comv.html, 9 April (downloaded 28 April 2009).

Cliff, R., M. Burles, M. Chase, D. Eaton and K. Pollpeter (2007) Entering the Dragon’s Lair: Chinese Anti-access Strategies and Their Implications for the United States, Santa Monica: Rand Corporation, Rand Project Air Force.

Economist, The (2004) “'Asian Currencies: A Need for Flexibility,”' 4 December, pp. 63-65.

Economy, E. and A. Segal (2009) “'Why the United States and China are Not Ready to Upgrade Ties,” Foreign Affairs, 88, pp. 14-23.

Ferguson, N. (2008) The Ascent of Money: A Financial History of the World, London: Allen Lane.

Friedberg, A. (2000) “'The Struggle for Mastery in Asia,’' Commentary, 110, pp. 17-26.

Gale, F., B. Lohmar and F. Tuan (2005) “'China’s New Farm Subsidies,” US Department of Agriculture, February, http://www.ers.usda.gov/publications/WRS0501 (downloaded 30 June 2006).

Greene, M., N. Dihel, P. Kowalski and D. Lippoldt (2006) '“China’s Trade and Growth: Impact on Selected OECD Countries,’’ OECD Trade Policy Working Paper, No. 44. OECD, http:// appli1.oecd.org/olis/2006doc.nsf/linkto/td-tc-wp(2006)10-final, 28 November (downloaded 25 June 2007).

Huntington, S. (2005) Who Are We? America’s Great Debate, London: The Free Press.

IMF (2005) World Economic Outlook, Washington DC: International Monetary Fund, September.

Jiang, D. (2007) '“US Loses Trade Volume Due to Export Controls on China - China Commerce Ministry,”' AFX News Limited, Forbes, http://www.forbes.com/business/feeds/afx/2007/06/22/ afx3847823.html, 22 June (downloaded 25 June 2007).

Johnson, S. (2009) “'The Quiet Coup,’” The Atlantic, http://www.theatlantic.com/doc/200905/imf_advice, May (downloaded 30 March 2009).

Justice Policy Institute (JPI) (2007) “'Education and Public Safety,’’ http://www.justicepolicy.org/images/ upload/07-08_REP_EducationAndPublicSafety_PS-AC.pdf (downloaded 19 April 2009).

Kessler, G. (2005) “'US Says China Must Address Its Intentions: How Its Power Will Be Used is of Concern,” Washington Post, 22 September, p. A16, http://www.washingtonpost.com/wp-dyn/content/ article/2005/09/21/AR2005092101912.html (downloaded 4 December 2008).

Kiely, R. (2008) “'Poverty Falls/China’s Rise: Global Convergence or New Forms of Uneven of Development,” Journal of Contemporary Asia, 38, 3, pp. 353-72.

Kissinger, H. (2004) “'America’s Assignment,” Newsweek, 9 November, pp. 26-31.

Kurlantzick, J. (2006) “'China’s Charm: Implications of Chinese Soft Power,’ Policy Brief, No. 47, Carnegie Endowment for International Peace, http://carnegieeurope.eu/publications/?fa1/418401, June (downloaded 12 May 2009).

Lampton, D. (2005) '“Paradigm Lost: The Demise of 'Weak China,'” National Interest, autumn, pp. 67-74.

Lau, L. (2003) 'Is China playing by the rules? Free Trade, Fair Trade, and WTO Compliance,'” Testimony at a hearing of the Congressional-Executive Commission on China, http://www.stanford.edu/*ljlau/ RecentWork/RecentWork/030924.pdf, 24 September (downloaded 25 June 2007). 
Lau, L., X. Chen, L. Cheng, K.C. Fung, J. Pei, Y. Sung, Z. Tang, Y. Xiong, C. Yang and K. Zhu (2006) “'Estimates of US-China Trade Balances in Terms of Domestic Value-Added,’' Stanford Center for International Development, Stanford University, Working Paper No. 295, http://siepr.stanford.edu/ publicationsprofile/1059 (downloaded 25 June 2007).

Liew, L. (2000) “'China’s Economic Reform Experience: The End of a Parto-Improving Strategy,’’ China Information, 14, pp. 129-168.

Linden, G., K. Kraemer and J. Dedrick (2009) '“Who Captures Value in a Global Innovation Network? The Case of Apple's iPod,'” Communications of the ACM, 52, pp. 140-4.

McCormick, D. (2007) “'Rebalancing the US-China Economic Relationship,’' Remarks delivered at Peking University, 20 September, Press Room, Department of the Treasury, http://www.treas.gov/ press/releases/hp566.htm (downloaded 24 September 2007).

Mckinnon, R. (2005a) “Exchange Rate or Wage Changes in International Adjustment? Japan and China Versus the United States,’’ Economics Department Working Paper, http://www.stanford.edu/ *mckinnon/papers/swpo5007.pdf, May (downloaded 13 August 2006).

Mckinnon, R. (2005b) “'China’s New Exchange Rate Policy: Will China Follow Japan into a Liquidity Trap?’ http://www.stanford.edu/*mckinnon/papers/Weekly Economist_Oct_2005.pdf (downloaded 13 August 2006).

National Bureau of Statistics (NBS) (2006) 2006 Statistical Yearbook, Beijing: China Statistics Press.

National Bureau of Statistics (NBS) (2009) 2009 Statistical Yearbook, Beijing: China Statistics Press.

Nolan, P. (2002) '“China and the Global Business Revolution,’’ Cambridge Journal of Economics, 26, 1, pp. 119-37.

Nye, J. Jr. (2005) “'The Rise of China’s Soft Power,’ The Wall Street Journal Asia, 29 December, Harvard University: Belfer Center for Science and International Affairs, John F. Kennedy School of Government, http://bcsia.ksg.harvard.edu/publication.cfm?ctype¹/4article\&item_id1/1/41350 (downloaded 18 June 2007).

Obama, B. (2007) ' 'Obama to Paulson: Defend American Workers and Businesses by Challenging China’s Currency Manipulation,’’ http://obama.senate.gov/press/070613-obama_to_paulso/ (downloaded 6 July 2007).

OECD (2006) OECD Science and Technology Outlook, Paris: OECD.

Prasad, E. and T. Rumbaugh (2004) “'Overview”' in Prasad, E. (ed.) “China’s Growth and Integration into the World Economy: Prospects and Challenges,’’ Washington DC: International Monetary Fund, Occasional Paper No. 232.

Preeg, E. (2005) “The Rapid Development of China’s Advanced Technology Industry and its Impact on Military Modernization,” in K. Weinstein (ed.), China’s New Great Leap Forward: High Technology and Military Power in the Next Half-Century, Cicero: Hudson Institute, pp. 1-30.

Ravallion, M. (2004) “'Looking Beyond Averages in the Trade and Poverty Debate,’ Washington DC: World Bank, Policy Research Working Paper 3461, November.

Reserve Bank of Australia (RBA) (2007) “'Official Reserve Assets,’’ Monthly Statistical Release, http:// www.rba.gov.au/Statistics/official_reserve_asset.html\#table2 (downloaded 18 August 2007).

Roach, S. (2004) “'US Imbalances and Global Rebalancing: Implications for the Chinese Economy,” Beijing: China Development Research Foundation, http://report.drc.gov.cn/cdrf/enforum.nsf/0/ 7e3e5485885546a248256eb3003236d7?OpenDocument (downloaded 22 December 2004).

Rodrik, D. (2006) “'What’s so Special about China’s Exports?’' NBER Working Paper, No. 11947, January.

Rogers, D. (2006) “'How did We Get Back to Big Deficits? (\& What Can We Do Now?),” The Brookings Institution, http://www.utexas.edu/lbj/webcasts/concord/fiscalwakeup_rogers.pdf, September (downloaded 8 June 2007).

Scholl, R. (1999) “'The Net International Investment Position of the United States at Yearend 1998,' Bureau of Economic Analysis, http://www.bea.gov/scb/pdf/internat/BPA/1999/0799iip.pdf (downloaded 20 April 2009).

Shanghai caijing daxue jinrong xueyuan (SCD) (2004) Zhongguo jinrong fazhan baogao [China Finance Development Report], Shanghai: Shanghai caijing daxue chubanshe.

Tebbs, J. (2007) “'Pruning the Defense Budget,’ Budget Options Series, The Brookings Institution, http:// www3.brookings.edu/views/papers/200701tebbs.pdf, January (downloaded 8 June 2007).

Thompson, C. (2007) “The Scramble for Africa’s Oil,’” New Statesman, reprinted in Review, The Australian Financial Review, 22 June, p. 3.

UNDP (2005) Human Development Report, Geneva: United Nations Development Programme http:// hdr.undp.org/reports/global/2005 (download 4 August 2006).

US Census Bureau (UCB) (2008) “'Top Trading Partners,” Foreign Trade Statistics, http://www.census. gov/foreign-trade/statistics (downloaded 3 March 2009).

US-China Economic and Security Review Commission (USCC) (2004) Report to Congress, One hundred eight Congress, Second Session, June, Washington DC: US Government Printing Office.

US-China Economic and Security Review Commission (USCC) (2006) Report to Congress, One hundred ninth Congress, Second Session, November, Washington DC: US Government Printing Office.

US-China Economic and Security Review Commission (USCC) (2007) Report to Congress, One hundred tenth Congress, 
First Session, 1 June, Washington DC: US Government Printing Office.

US Department of Defence (USDOD) (2004) FY04 Report to Congress on PRC Military Power: Pursuant to the FY2000 National Defense Authorization Act, http://www.defenselink.mil/pubs/d20040528PRC. pdf (downloaded 29 August 2006).

US Department of the Treasury (USDT) (2009) Major Foreign Holders of Treasury Securities, Treasury International Capital System, http://www.treas.gov/tic/mfh.txt, 27 February (downloaded 9 March 2009).

US Government (USG) (2009) Historical Tables, Budget of the United States Government, Fiscal Year 2008, Washington, DC: Government Printing Office.

Victor, D., J. Deutch and J. Schlesinger (2008) Consequences of US Oil Dependency, New York: Council on Foreign Relations, Independent Task Force Report 58, July, Modification of 2006 report, http://

pesd.stanford.edu/publications/national_security_consequences_of_us_oil_dependency/(downloaded 28 April 2009).

Wallerstein, M. (2009) “'Losing Controls: How U.S. Export Restrictions Jeopardize National Security and Harm Competitiveness,”’ Foreign Affairs, 88, pp. 11-18.

Wang, W. and Q. Zeng (2004) Renminbi huilu“: tiaozhan yu biange xuanze [Renminbi exchange rate: challenge and choice of transformation], Beijing: Guangming ribao chubanshe.

World Bank (1997) China 2020, Washington DC: The World Bank.

World Bank (2009a) China Quarterly Update, Beijing: World Bank Office, March.

World Bank (2009b) From Poor Areas to Poor People: China’s Evolving Poverty Reduction Agenda - An Assessment of Poverty and Income Inequality in China, Poverty Reduction and Economic Management Department, East Asia and Pacific Region, World Bank, March.

WTO (2009) “'World Trade 2008, Prospects for 2009,’’ Press Release 23 March, http://www.bsa-bg.com/ images/circs/wto_2008.pdf (downloaded 20 April 2009).

Xinhuashe (2006) “'Ba goujian shehuizhuyi he hemu shehui baizai gengjia tuchu diwei”, [Place the establishment of a socialist and harmonious society in an even more prominent position], Renmin ribao [People’s Daily], 12 October, p. 1. 